\title{
PENGARUH IKLAN ZAKAT MELALUI MEDIA ONLINE TERHADAP LOYALITAS MUZAKI DI BADAN AMIL ZAKAT NASIONAL (BAZNAS) PROVINSI BALI
}

Iswahyuni, S.P, M.MA

\author{
Sekolah Tinggi Agama Islam Denpasar Bali \\ E-mail: iswahyunijenar@gmail.com \\ HP/ WA : 081936086548
}

\begin{abstract}
ABSTRAK
Pemasaran mempunyai peran penting bagi keberlanjutan perusahaan. Melalui pemasaran, hasil produksi dapat diperkenalkan, dan dibeli oleh konsumen. Apabila hasil produksinya baik, dapat menimbulkan kepuasan di hati konsumen maka mereka akan tertarik dan menjadi langganan di suatu produk yang kita kenalkan.Rumusan masalah penelitian ini adalah 1. Apakah ada pengaruh iklan zakat secara signifikan terhadap loyalitas muzaki di Baznas Provinsi Bali? 2. Apakah ada pengaruh signifikan antara media online terhadap loyalitas muzakki di Baznas Provinsi Bali?. 3. Apakah ada pengaruh iklan zakat melalui media online secara simultan terhadap loyalitas muzaki di Baznas Provinsi Bali?.Tujuan Penelitian ini adalah 1. Untuk mengetahui pengaruh signifikan antara variabel iklan terhadap loyalitas muzaki di Baznas Provinsi Bali 2. Untuk mengetahui pengaruh yang signifikan dari variabel media online terhadap variabel loyalitas muzaki di Baznas Provinsi Bali 3. Untuk mengetahui pengaruh iklan zakat melalui media online.Metode pada penelitian ini menggunakan penelitian kuantitatif dengan melakukan survei. Populasi pada penelitian ini adalah muzakki di Baznas Provinsi Bali. Teknik pengambilan sampel menggunakan metode purposive sampling dengan jumlah sampel sebanyak 43 orang. Teknik pengumpulan data menggunakan kuesioner. Teknik analisis data yang digunakan untuk menjawab hipotesis adalah uji regresi berganda dan uji asumsi klasik dengan menggunakan SPSS for windows 7 versi 25 . Dari hasil pengolahan data menggunakan SPSS ditemukan hasil penelitian bahwa uji regresi berganda adalah 1,425 0.221 dan 0.223 serta hasil uji koefisien determinasi R2 sebesar 0,555 dengan nilai signifikan $0,00<0,05$ dengan secara simultan sebesar 24,934 $>3,23$ dengan signifikan 0,00 besarnya nilai loyalita muzaki tersebut menunjukkan adanya pengaruh antara iklan zakat melalui media online terhadap loyalitas muzaki di Baznas Provinsi Bali baik secara parsial atau terpisah maupun secara simultan.
\end{abstract}

\section{Kata kunci: Iklan, Media Online, Loyalitas}

\section{ABSTRACT}

Marketing has an important role for the sustainability of the company. Through marketing, products can be introduced, and purchased by consumers. If the production is good, it can lead to satisfaction in the hearts of consumers, so they will be interested and become customers in a product that we introduce.The formulation of the research problem is 1 . Is there a significant influence of zakat advertising on muzaki loyalty in Baznas, Bali Province? 2. Is there a significant influence between online media on muzakki loyalty in Baznas, Bali Province?. 3. Is there a simultaneous influence of zakat advertising through online media on muzakki loyalty in Baznas, Bali Province?

The objectives of this study were 1 . To determine the significant effect of advertising variables on muzakki loyalty in Baznas, Bali Province 2. To determine the significant effect of online media variables on muzakki loyalty variables at Baznas, Bali Province 3. To determine the effect of zakat advertising through online media.The method in this study uses quantitative research by conducting a survey. The population in this study were muzakki in Baznas, Bali Province. The sampling technique used purposive sampling method with a total sample of 43 people. Data collection techniques using a questionnaire. The data analysis technique used to answer the hypothesis is multiple regression test and classical assumption test using SPSS for windows 7 version 25. From the results of data processing using SPSS, it was found that the multiple regression test was $1,4250.221$ and 0.223 and the results of the coefficient of determination R2 were 0.555 with a significant value of $0.00<0.05$ with a simultaneous $24,934>3.23$ with a significant 0.00 The magnitude of the value of muzakki loyalty shows that there is an influence between zakat advertising through online media on muzakki loyalty in the Baznas of Bali Province, either partially or separately or simultaneously. 


\section{PENDAHULUAN}

Iklan zakat pada masa ini mulai menjadi magnet bagi masyarakat Indonesia pada umumnya dan media online seperti instagram, facebook, whatshapp dan twiter. ${ }^{1}$ Hal ini merupakan suatu hal yang positif bagi perkembangan Badan Amil Zakat di suatu daerah tertentu. Banyak manfaat adanya iklan zakat melalui media online ini dengan banyak mengajak masyarakat sekitar untuk berzakat di lembaga ini dari ajakan zakat fitrah maupun zakat maal atau zakat harta.

Periklanan memegang peranan cukup penting sebagai bagian dari industri modern yang dewasa ini berlangsung. ${ }^{2}$ Kebutuhan akan adanya iklan berkembang seiring dengan perkembangan pesat pertumbuhan penduduk dan kota-kota yang kini dipenuhi oleh toko, restoran, maupun pusat-pusat perdagangan dan penyedia jasa. Perkembangan iklan juga didukung oleh perkembangan pesat media cetak mapun elektronik yang sangat pesat.

Definisi pemasaran ini bersandar pada konsep inti dari kegiatan marketing yang meliputi kebutuhan, keinginan, dan permintaan. Manusia harus menemukan kebetuhannya terlebih dahulu, sebelum ia memenuhinya. Usaha untuk memunuhi kebutuhan tersebut dapat dilakukan dengan cara mengadakan suatu hubungan. Dengan demikian, pemasaran bisa juga diartikan sebagai suatu usaha untuk memuaskan kebetuhan pembeli dan penjual.

Melalui kegiatan pemasaran masyarakat akan menilai bahwa produk yang dipasarkan adalah produk yang tepat untuk memenuhi kebutuhan hidup mereka. Tetapi pratiknya, kegiatan memahami kebutuhan masyarakat bukanlah hal yang mudah, beberapa masyarakat mungkin mempunyai kebutuhan yang tidak sepenuhnya mereka sadari atau mereka tidak bisa mengartikulasikan kebetuhan mereka.

Promosi dalam bidang dakwah sosial sebenarnya tidak jauh berbeda dengan promosi yang dilakukan oleh para pelaku ekonomi pada umumnya. Promosi digunakan untuk menginformasikan kepada donatur dan muzaki

${ }^{1}$ Ekasari. Pengaruh Promosi Berbasis Sosia Media TerhadapKeputusan Pembelian Produk Jasa Pembiayaan. Jurnal Penelitian Universitas Jambi Seri Humaniora 2014. h. 81.

${ }^{2}$ Murshid, M. Manajemen Pemasaran.

Jakarta: PT Bhumi Aksara. h.218 mengenai produk-produk OPZ (Organisasi Pengelola Zakat) dan meyakinkan kepada donatur dan muzaki dalam masyarakat tertentu untuk bersimpati dan mendukung terhadap program dan kegiatan yang akan dilakukannya. Dengan adanya promosi, lembaga zakat akan dikenal oleh masyarakat luas, mampu mempengaruhi untuk membayarkan zakatnya, melahirkan kepercayaan, sehingga dapat meningkatkan perolehan dana zakat.

Tujuan dari pemasaran adalah untuk memberikan kepuasan terhadap konsumen. Meskipun demikian, pemasaran juga mendapat stigma sebagai tempat bagi para produsen mengeruk keuntungan yang sebesar besarnya dari para konsumen. Tidak heran jika masih banyak konsumen yang menjadi korban iklan dan membeli barang yang tidak dibutuhkan Pemasaran dapat dikatakan beretika ketika memenuhi dua unsur utama yaitu bersikap lemah lembut/ sopan santun, dan tidak menggunakan cara yang bathil, realistis dan bertanggung jawab. Suatu bisnis dilarang jika oleh syariat Islam jika didalamnya mengandung unsur tidak halal, atau merampas hak kekayaan orang lain

Larangan menggunakan dengan cara yang bathil disebutkan dalam Al-Qur'an Surah AnNisa ayat $29^{3}$ :

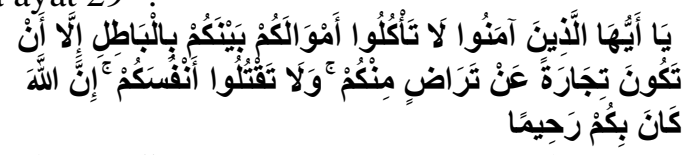

Artinya :"Hai orang-orang yang beriman, janganlah kamu saling memakan harta harta-harta saudaramu dengan cara yang batil, kecuali harta itu diperoleh dengan jalan dagang yang ada saling kerelaan dari antara kamu. Dan jangan kamu membunuh diri-diri kamu, karena sesungguhnya Allah Maha Pengasih kepadamu." (QS. AnNisa 4:29).

Berdasarkan ayat diatas, telah jelas bahwa Allah Swt mengingatkan kepada orang-orang beriman untuk tidak memakan atau memperoleh harta yang menjadi sarana kehidupan mereka dengan cara yang batil atau tidak sesuai dengan

3 Kementrian Agama, Ri, Al-Quran dan Terjemahannya (Jakarta: PT.Sinergi Pustaka Indonesia 2012, h.125. 
ajaran Islam. Menekankan juga keharusan mengindahkan peraturan-peraturan yang ditetapkan atau persyaratan yang disepakati bersama selama tidak menghalalkan yang haram atau mengharamkan yang halal. Prinsip pemasaran berbasis syariah tidak bersifat eksklusif, fanatis, anti modernitas, dan kaku. Selain itu, pemasaran berbasis syariah bersifat fleksibel, sebagaimana keluasan dan keluesan hukum Islam. Iklan dipahami sebagai upaya proses mempengaruhi masyarakat baik perorangan, masyarakat, individu maupun instansi dan lembaga agar menyalurkan dana kepada sebuah organisasi. Iklan lebih banyak dilakukan secara langsung kepada personal atau lembaga. ${ }^{4}$

Dalam kajian ulama tentang zakat di era modern disebutkan beberapa alasan kewajiban berzakat salah satunya zakat profesi/penghasilan, antara lain yaitu dari sudut keadilan yang merupakan ciri utama dari ajaran agama Islam, penetapan kewajiban zakat pada setiap harta yang dimiliki akan terasa sangat jelas dibandingkan dengan hanya menetapkan kewajiban zakat pada komoditas-komiditas tertentu yang bersifat konvensional. Sejalan dengan perkembangan kehidupan manusia, khususnya dalam bidang ekonomi, kegiatan penghasilan melalui keahlian dan profesi ini telah berkembang dari waktu ke waktu. Bahkan akan menjadi kegiatan ekonomi yang paling utama, seperti yang terjadi dinegara-negara industri saat ini, penetapan kewajiban zakat kepadanya menunjukkan betapa sangat aspiratif dan responsif terhadap hukum Islam dan perkembangan zaman kontemporer seperti saat ini, karena keberkahan akan terjadi ketika seorang sudah mengeluarkan zakatnya ketika telah mencapai nishab.

Perhitungan zakat penghasilan/profesi sesuai Peraturan Menteri Agama No. 52 tahun 2015 tentang syarat dan cara perhitungan zakat maal dan zakat fitrah serta pendayagunaan zakat usaha produktif, pada pasal 26 dan 27 bahwa zakat pendapatan dipungut setelah mencapai nilai $653 \mathrm{~kg}$ gabah atau 524 beras rincian sebagai berikut: kalau dihitung secara detail dengan harga beras misalnya Rp. 10.000,- , maka 524 x 10.000,- = Rp. 5.240.000 sehingga setiap orang yang berpenghasilan perbulannya

4 April Purwanto, Manajemen Fundrising bagi Organisasi Pengelola Zakat, Teras, Yogyakarta, 2009, h. 39. minimal dengan angka perhitungan sebesar nominal diatas maka wajib mengeluarkan zakatnya dengan kadar 2,5\% yaitu Rp. 131.000,- Dengan mengeluarkan sebagian kecil harta pendapatan/penghasilan yang kita jalani dengan nominal yang sangat kecil tapi dibalik dari nilai itu merupakan keberkahan yang sangat besar dan berbuah pahala kebaikan yang akan kita terima didunia maupun di akhirat kelak.

Sehubungan dengan itu, penulis tertarik untuk mengetahui lebih mendalam tentang pengaruh iklan zakat melalui media online dan leterasi digital pengoptimalan dan efektif pengaruhnya terhadap loyalitas muzaki untuk berzakat di lembaga tersebut. Oleh karena itu, penulis melakukan penelitian yang mengangkat judul: Pengaruh Iklan Zakat Melalui Media Online Terhadap Loyalitas Muzaki di Badan Amil Zakat Nasional (Baznas) Provinsi Bali.

Berdasarkan uraian latar belakang tersebut diatas, maka permasalahan dalam penelitian ini dapat dirumuskan sebagai berikut: 1)Apakah ada pengaruh iklan zakat terhadap loyalitas muzaki di Baznas Provinsi Bali? 2)Apakah ada pengaruh media online terhadap loyalitas muzaki di Baznas Provinsi Bali? 3)Apakah ada pengaruh iklan zakat melalui media online secara simultan terhadap loyalitas muzaki di Baznas Provinsi Bali?

Tujuan penelitian ini adalah untuk mengetahui; 1)Untuk mengetahui tentang pengaruh iklan zakat melalui loyalitas terhadap muzaki di Baznas Provinsi Bali. 2)Untuk mengetahui pengaruh media online terhadap loyalitas muzaki di Baznas Provinsi Bali. 3)Untuk mengetahui pengaruh iklan zakat melalui media online secara simultan terhadap loyalitas muzaki di Baznas Provinsi Bali.

Hipotesis merupakan jawaban sementara terhadap perumusan penelitian. Dimana rumusan masalah penelitian telah dinyatakan dalam bentuk kalimat pertanyaan. Maka hipotesis awal yang di kemukakan. ${ }^{5}$ Ha1:Ada pengaruh yang signifikan antara variabel iklan zakat $\left(\mathrm{x}_{1}\right)$ terhadap loyalitas muzaki (y) di Baznas Provinsi Bali Ha2 : Ada pengaruh yang signifikan antara media online ( $\left.\mathrm{x}_{2}\right)$ terhadap variabel loyalitas muzaki (y) di Baznas Provinsi Bali Ha3 : Secara simultan ada pengaruh positif

${ }^{5}$ Abdul Muhid, Analisis Statistik (5 langkah Analisis Statistik dengan SPSS For Windows Sidoarjo:Zitama, Cet.1 Ke 1 hal. 13 thn 2011. 
antara iklan zakat $\left(\mathrm{x}_{1}\right)$ melalui media online (x2) terhadap loyalitas muzaki di Baznas Provinsi Bali (Y).

\section{METODE PENELITIAN}

Penelitian ini menggunakan pendekatan kuantitatif, yakni penelitian yang menganalisis data-data secara kuantitatif kemudian menginterpresikan suatu kesimpulan. ${ }^{6}$ Penelitian kuantitatif merupakan penelitian yang menggunakan angka mulai dari pengumpulan data, penafsiran terhadap data, serta penampilan hasilnya. Angka-angka tersebut diperoleh melalui penyebaran kuesioner kepada para responden, yakni muzaki di Baznas Provinsi Bali. Kemudian membuat gambaran mengenai situasi atau kejadian, menerangkan hubunganhubungan, menguji hipotesis-hipotesis, membuat prediksi, serta mendapatkan makna dan implikasi dari suatu masalah yang ingin dipecahkan. ${ }^{7}$

Populasi dalam penelitian ini adalah muzaki di Baznas Provinsi Bali. Berdasarkan laporan data yang diberikan pihak Baznas tahun 2020 yaitu 124 muzaki di Baznas Provinsi Bali. Tingkat variasi populasi memberikan pengaruh dalam menentukan ukuran sampel. Jumlah yang dijadikan populasi muzaki pada Baznas Provinsi Bali ialah berjumlah 124 muzaki. Sampel yaitu bagian dan jumlah karakteristik yang dimilki populasi tersebut. Sebagian dari jumlah dan karakteristik yang dimiliki oleh populasi tersebut. ${ }^{8}$ Pembagian jenis sampel yang diterapkan oleh Sugiyono ada berbagai macam. Diantaranya penulis menerapkan dalam penelitian dengan menggunakan Purposive Sampling/sampel penilaian yaitu teknik pengambilan sampel dengan menentukan kriteria- kriteria tertentu adapun jumlah sampel untuk penelitian ini adalah 43 muzaki. ${ }^{9}$

Penelitian ini diawali dengan membaca hasil penelitian terdahulu untuk mendapatkan

${ }^{6}$ Moch Nazir, Metode Penelitian. Bogor : Ghalia Indonesia,h 67 Thn 2005.

${ }^{7}$ J. Supranto, M.A. Metode Ramalan Kuantitatif dan Perencanaan Ekonomi dan Bisnis. (Jakarta: PT. Rineka Cipta, 2000) hal 10.

${ }^{8}$ Sugiyono, Metode Penelitian Kuantitatif Kualitatif dan R\&D, (Bandung: Alfabeta 2011), hal 81.

${ }^{9}$ Sugiyono, Statistika Untuk Penelitian, Bandung: Alfabeta, 2017, Cet 26. gambaran awal terhadap topik masalah yang akan diteliti. Kemudian dilakukan identifikasi permasalahan yang akan diteliti. Untuk mendukung persiapan penelitian, maka sebelumnya juga dilakukan pengumpulan berbagai konsep dan teori melalui kajian pustaka serta observasi di tempat penelitian.

Selanjutnya membuat desain kuesioner yang akan dipakai untuk mendapatkan data dari masing-masing responden. Untuk menghindari kesalahan teknis maka sebelumnya dilakukan uji validitas dan reliabilitas.

Setelah itu dilanjutkan pengumpulan data awal yang sesuai dengan variabel-variabel yang diteliti. Berbagai data yang diperoleh, kemudian dilakukan identifikasi untuk memilah-milah data yang benar-benar bermanfaat. Selanjutnya dilaksanakan perhitungan dengan model statistik analisis regresi berganda. Hasil perhitungan tersebut akan memberi informasi tentang pengaruh iklan melalui media online terhadap loyalitas muzaki sehingga akhirnya dapat ditarik simpulan keseluruhan hasil penelitian yang dilakukan.

Dengan mempertimbangkan berbagai faktor antara lain kompleksnya masalah yang ada, maka pada penelitian ini dikaji hanya terbatas pada variabel iklan (X1) melalui media online (X2) dan loyalitas muzaki (Y).

Adapun kerangka berpikir, yakni untuk menggambarkan pengaruh variabel X1, X2 terhadap variabel $\mathrm{Y}$ pada penelitian ini adalah adanya pengaruh positif iklan zakat melalui media online terhadap loyalitas muzaki, sebagaimana pada gambar berikut. 


\begin{tabular}{|c|c|}
\hline $\begin{array}{l}\text { Iklan (X1) } \\
\text { - menarik perhatian } \\
\text { - cerdas dan cermat } \\
\text { - unik } \\
\text { - tidak rumit } \\
\text { - citra produk } \\
\text { - informatik } \\
\text { - keunggulan } \\
\text { - cita rasa }\end{array}$ & $\begin{array}{l}\text { Media Online (X2) } \\
\text { - Jaringan Arsip } \\
\text { - Interaksi } \\
\text { - Simulasi sosial } \\
\text { - konten pengguna } \\
\text { - sharing/penyebaran }\end{array}$ \\
\hline
\end{tabular}

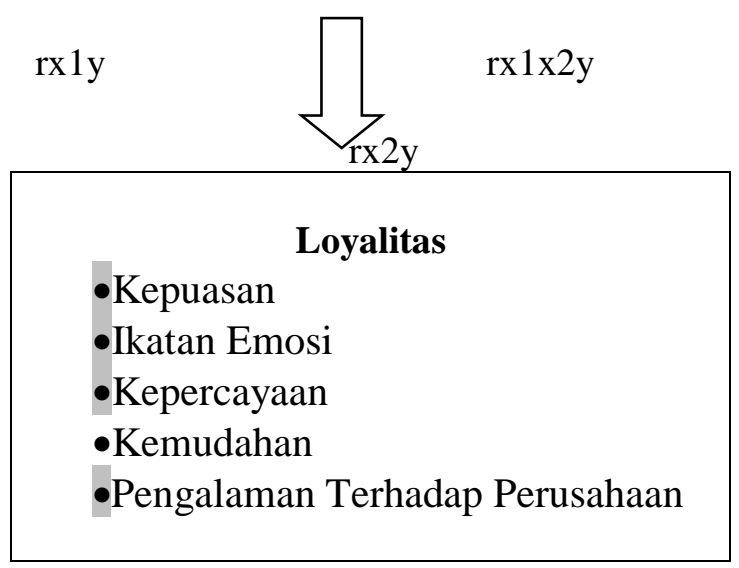

Gambar 2.1 Gambar Kerangka Berfikir

Keterangan:

\begin{tabular}{|c|c|}
\hline $\mathrm{X} 1$ & $\begin{array}{l}\text { : Variabel independen, yaitu iklan } \\
\text { zakat }\end{array}$ \\
\hline $\mathrm{X} 2$ & $\begin{array}{l}\text { : Variabel independen, yaitu media } \\
\text { online }\end{array}$ \\
\hline$Y$ & : Variabel dependen, yaitu loyalitas \\
\hline $\mathrm{v}$ & $\begin{array}{l}\text { : Regresi Variabel pengaruh Iklan } \\
(\mathrm{x} 1) \text { terhadap variabel loyalitas }\end{array}$ \\
\hline & $\begin{array}{l}\text { Regresi Variabel media online }\left(\mathrm{x}_{2}\right) \\
\text { terhadap loyalitas muzaki }\end{array}$ \\
\hline $\mathrm{rX} 1, \mathrm{X} 2 \mathrm{Y}$ & $\begin{array}{l}\text { : Regresi variabel pengaruh iklan } \\
\text { (x1), melalui media online (X2) } \\
\text { terhadap loyalitas muzaki (Y) }\end{array}$ \\
\hline
\end{tabular}

\section{HASIL DAN PEMBAHASAN}

Dalam menentukan hasil penelitian ini digunakan responden yang terdiri dari 43 muzaki, yakni: responden berjenis kelamin Laki-laki sebanyak $67 \%$ atau 26 orang dan Perempuan sebanyak $33 \%$ atau 14 orang, berdasarkan usia responden yang berusia 20-35 tahun sebanyak $70 \%$ atau 25 orang, usia $36-45$ sebanyak $4 \%$ atau 8 orang dan untuk usia $46-55$ sebanyak $26 \%$ atau 10 orang, untuk wilayah responden muzaki Baznas Provinsi Bali $40 \%$ berasal dari Kabupaten Jembrana dan Kota Denpasar yang berjumlah masing 14 orang, 3\% berasal dari kabupaten Tabanan dan Kabupaten Badung berjumlah 4 dan 5 responden, sedangkan untuk kabupaten lainnya hanya $4 \%$ yaitu hanya 6 orang, dan untuk pekerjaan responden kebanyakan bekerja swasta yaitu 41 $\%$ berjumlah 18 orang sedangkan pedagang 33 $\%$ yaitu berjumlah 15 orang dan PNS hanya $11 \%$ yaitu 5 orang , 7,5\% lagi berasal dari responden yang bekerja sebagai petani atau yang lainnya yaitu berjumlah 3 orang, dan untuk yang memliki media sosial/online seperti Whatshap, Instagram, Facebook, dll adalah semua responden memiliki media sosial karena memudahkan berkomunikasi, dan menemukan suatu informasi dari media tersebut.

Untuk melihat hasil variabel kualitas jaringan dan strategi marketing terhadap variabel loyalitas pelanggan maka dilakukan uji-t dengan progaram SPSS Versi 25. Uji t dikenal dengan uji parsial, yaitu untuk menguji bagaimana pengaruh masingmasing variabel bebasnya secara sendirisendiri terhadap variabel terikatnya. Uji ini dapat dilakukan dengan membandingkan $t$ hitung dengan $t$ tabel atau dengan melihat kolom signifikansi pada masing-masing $\mathrm{t}$ hitung

\begin{tabular}{|c|c|c|c|c|c|}
\hline \multicolumn{6}{|c|}{ Coefficients $^{a}$} \\
\hline \multirow[b]{2}{*}{ Model } & \multicolumn{2}{|c|}{$\begin{array}{c}\text { Unstandar } \\
\text { dized } \\
\text { Coefficients }\end{array}$} & \multirow{2}{*}{\begin{tabular}{|c|}
$\begin{array}{c}\text { Sta } \\
\text { ndardiz } \\
\text { ed } \\
\text { Coeffic } \\
\text { ients }\end{array}$ \\
$\begin{array}{c}\text { Bet } \\
\mathrm{a}\end{array}$ \\
\end{tabular}} & & \\
\hline & B & $\begin{array}{r}\text { Std. } \\
\text { Error }\end{array}$ & & & ig. \\
\hline (Con & 1, & 2,8 & & & 0 \\
\hline stant) & 425 & 71 & & 497 &, 622 \\
\hline $\mathrm{x} 1$ & 0 . & 0,1 & 0.29 & & 0 \\
\hline & 221 & 38 & 9 & 595 & .119 \\
\hline $\mathrm{x} 2$ & 0 , & 0,0 & 0,47 & 2 & \\
\hline & 223 & 87 & & 551 & .015 \\
\hline
\end{tabular}

Sumber : Data Primer yang diolah, 2021

Dalam penelitian ini t tabel diperoleh angka tabel sebesar 1,497 Dari data diatas nilai Sig. $0.00<$ nilai $\mathrm{X} 1=1,595$ dan $\mathrm{X} 2=2,551$ yang artinya variabel (X1) Iklan zakat dan (X2) Media online berpengaruh signifikansi terhadap variabel (Y) Loyalitas muzaki.

Uji $F$ dikenal dengan uji serentak atau uji model atau uji Anova, yaitu uji untuk melihat bagaimanakah pengaruh semua variabel 
bebasnya secara bersama-sama terhadap variabel terikatnya. Atau untuk menguji apakah model regresi yang kita buat baik/signifikan atau tidak baik atau non signifikan.

Tabel 4.13 Uji F

\begin{tabular}{|c|c|c|c|c|c|}
\hline Model & $\begin{array}{c}\text { Sumo } \\
\mathrm{f} \\
\text { Squar } \\
\text { es }\end{array}$ & Df & $\begin{array}{c}\text { Mean } \\
\text { Square }\end{array}$ & $\mathrm{F}$ & $\begin{array}{c}\text { Sig } \\
\cdot\end{array}$ \\
\hline $\begin{array}{c}\text { Regres } \\
\text { sion }\end{array}$ & $\begin{array}{c}101,8 \\
10\end{array}$ & 2 & 53.283 & $\begin{array}{c}24,9 \\
34\end{array}$ & $\begin{array}{c}.00 \\
0^{\mathrm{b}}\end{array}$ \\
$\begin{array}{c}\text { Resid } \\
\text { ual }\end{array}$ & $\begin{array}{c}85,48 \\
0\end{array}$ & 40 & 2.137 & & \\
Total & $\begin{array}{c}192,0 \\
47\end{array}$ & 42 & & & \\
\hline
\end{tabular}

Sumber : Data yang diolah,2021.

Besarnya $F_{\text {hitung }}$ yang diperoleh dari hasil regresi dengan bantuan SPSS Versi 25. Hasil uji menentukan nilai $F_{\text {hitung }}$ sebesar 24,934 lebih besar dari pada $\mathrm{F}_{\text {tabel }}$ sebesar 3,23 dengan nilai signifikasi $0,000<0,05$ maka Ho ditolak dan $\mathrm{Ha}$ diterima, sehingga dapat disimpulkan bahwa, variabel Iklan zakat (X1) dan Media online (X2) berpengaruh signifikansi secara simultan terhadap variabel Loyalitas muzaki (Y). Berdasarkan dari hasil perhitungan koefisien determinasi (r2) sebesar 0,555 yang berarti Iklan Zakat dan media online memiliki pengaruh sebesar $55,5 \%$ terhadap Loyalitas muzaki dan sisanya $45,5 \%$ dipengaruhi oleh variabel lain. Berdasarkan hasil ujian normalitas nilai Asymp Sig yaitu ,012 (2-tailed) maka dapat disimpulkan data-data penelitian telah terdistribusi normal. Selanjutnya berdasarkan hasil analisis data diatas maka dapat disimpulkan bahwa: Variabel independen Iklan media online (X1) indikatornya : 1) Menarik perhatian. 2) Cerdas dan kreatif. 3) Unik. 4) Tidak rumit. 5) Citra produk. 6) Informatif. 7) Keunggulan 8) Cita rasa dan variabel Loyalitas Muzaki (Y) indikatornya: 1) Kepuasan 2) Ikatan Emosi 3) Kepercayaan 4) Kemudahan. 5) Pengalaman terhadap perusahaan Dari hasil analisis SPSS versi 25 maka diperoleh hasil bahwa: Iklan zakat (X1) terhadap Loyalitas muzaki (Y) memiliki tingkat Sig, sebesar 0,000.
Karena nilai signifikansi $\mathrm{t}<0,01$ maka Ho ditolak dan $\mathrm{H} 1$ diterima. Artinya terdapat :

1.Pengaruh iklan zakat terhadap loyalitas muzaki di Baznas Provinsi Bali.

Hasil penelitian menunjukkan bahwa variabel Iklan zakat diperoleh nilai t hitung sebesar 1,595 dengan nilai signifikansi sebesar 0,000 lebih kecil dari $0,05(0,000<0,05)$, dan koefisien regresi mempunyai nilai positif sebesar 1,425 maka penelitian ini berhasil membuktikan hipotesis pertama yang menyatakan bahwa "Iklan zakat memiliki pengaruh yang signifikan terhadap loyalitas muzaki di Baznas Provinsi Bali.

\begin{tabular}{|c|l|c|c|c|}
\hline \begin{tabular}{|c|c|} 
Mode \\
$\mathbf{l}$
\end{tabular} & $\mathbf{R}$ & $\begin{array}{c}\mathbf{R} \\
\text { Squar } \\
\mathbf{e}\end{array}$ & $\begin{array}{c}\text { Adjuste } \\
\mathbf{d} \text { R } \\
\text { Square }\end{array}$ & $\begin{array}{c}\text { Sd. } \\
\text { Error } \\
\mathbf{f} \text { the } \\
\text { Estim } \\
\mathbf{a e}\end{array}$ \\
\hline 1 & $\begin{array}{c}.745 \\
\mathrm{a}\end{array}$ & .555 & .533 & 1,462 \\
\hline \multicolumn{2}{|c|}{ Dan } & \multicolumn{2}{|c|}{ berdasarkan } & hasil perhitungan \\
\hline
\end{tabular}
determinasi X1 dan X2 adalah sebesar 55.5\% yang artinya Iklan zakat dan media online memiliki pengaruh yang cukup besar terhadap terhadap loyalitas muzaki di Baznas Provinsi Bali Sedangkan sisanya adalah 45,5\% dipengaruhi oleh faktor-faktor yang lain yang tidak diteliti dalam penelitian ini.

Iklan zakat adalah kesesuaian antara keputusan berzakat dan adanya ketertarikan dalam suatu minat. Iklan zakat dapat mempengaruhi loyalitas muzaki dalam mengeluarkan zakat di Baznas Provinsi Bali, karena jika Iklan zakat dapat menarik perhatian yang di terima dengan banyaknya kepercayaan untuk berzakat, maka muzaki tentu memilih Amil zakat yang membangkitkan hati nurani untuk selalu berzakat di Baznas Provinsi Bali.

Menurut Wibowo Iklan adalah suatu elemen komunikasi pemasaran yang persuasif, nonpersonal. dibayar oleh sponsor dan disebarkan melalui sealuran komunikasi massa untuk mempromosikan pemakaian barang atau jasa. Selain itu fungsi iklan adalah sebagai berikut yaitu : Memberi informasi yaitu dapat memberitahukan pasar tentang suatu produk, program, menyusulkan kegunaan suatu produk baru menjelaskan cara kerja, dan membangun citra perusahaan. Membujuk periklanan dapat membentuk suatu referensi, mengubah persefsi 
konsumen tentang atribut produk atau jasa yang diiklankan. Memberikan nilai tambah dalam arti mempengaruhi persepsi konsumen, sehingga seringkali suatu merk lebih menjadi lebih berkelas, dan lebih bergaya.

Penelitian ini sejalan dengan penelitian yang dilakukan oleh Astuti Mustikawati yang berjudul "Pengaruh promosi untuk meningkatkan minat zakat di Baznas Kota Bandung" mengungkapkan bahwa promosi mempunyai pengaruh yang tinggi untuk menarik dan meningkatkan minat seseorang. Berdasarkan riset yang dilakukan di Baznas pada tahun 2011 menunjukkan zakat adalah kecakapan organisasi pengelola zakat, tingkat keimanan, tingkat kepedulian sosial. Tentunya kualitas promosi yang baik adalah yang memberikan informasi yang jelas juga relevan. ${ }^{10}$

2. Pengaruh media online terhadap loyalitas muzaki di Baznas Provinsi Bali.

Hasil penelitian menunjukkan bahwa variabel media online diperoleh nilai t hitung sebesar 2,551 dengan nilai signifikansi sebesar 0,000 lebih kecil dari $0,05(0,000<0,05)$, dan koefisien regresi mempunyai nilai positif sebesar 1,425, maka penelitian ini berhasil media online digital memiliki pengaruh yang signifikan terhadap loyalitas Muzakki di Baznas Provinsi Bali

Menurut Richard mengklaim bahwa media online telah memperluas jangkauan semantiknya dari makna "kemampuan mengakses dan memudahkan tanpa keluar rumah" dengan berkembangnya era digital, yaitu mampu memahami informasi berdasarkan format digital, masyarakat dimungkinkan mengubah, memformat ulang, menstransformasikan gambar, suara, dan kata-kata secara bebas menjadi sekarang yang berarti "kemampuan untuk memahami infomasi yang disajikan ${ }^{11}$. Media online mempunyai peran yang semakin penting dalam kehidupan umat manusia, sada berpendapat bahwa tingginya pemahaman akan teknologi bagi umat muslim merupakan unsur yang terpenting untuk memperoleh kesejahteraan umat manusia.

10 Astuti Mustikawati, Pengaruh promosi untuk meningkatkan minat zakat di Baznas Kota Bandung (Survei Mahasiswa Fakultas Ekonomi dan Bisnis Universitas Islam Bandung), pada 20 maret 2021.

11 Richard L. Anham, Digital Literacy Scienti American, Vol 237 No 3 1995, h. 198-200.
Penelitian ini sejalan dengan penelitian yang dilakukan oleh Afiful Icwan yang meneliti mengenai Pengaruh Media online Terhadap Keputusan muzaki membayar Zakat Infak dan Shadaqah Melalui Fintech Go-pay Pada Baznas". (Survey Mahasiswa Fakultas Ekonomi dan Bisnis Universitas Islam Negeri Intan Lampung )" Penelitian ini membahas adakah pengaruh media online terhadap keputusan muzakki membayar ZIS di Baznas Lampung.

Dari hasil penelitian tersebut dapat diperoleh kesimpulan bahwa, baik secara parsial variabel media online dan Teknologi Acceptance Model berpengaruh signifikan terhadap keputusan membayar Zakat Infaq dan Shadaqah di Baznas Kota Lampung.

3. Pengaruh iklan zakat melalui media online terhadap loyalitas muzaki di Baznas Provinsi Bali.

Dari hasil pengujian diperoleh nilai $F$ hitung sebesar 24,934 dengan signifikansi sebesar 0,000 . Oleh karena nilai signifikansi lebih kecil dari $0,05(0,000<0,05)$, maka penelitian ini mampu membuktikan hipotesis ke tiga yang menyatakan "Terdapat pengaruh Iklan zakat melalui media online secara bersama-sama terhadap loyalitas muzaki di Baznas Provinsi Bali.

Dua hal yang menjadi pertimbangan utama perusahaan dalam meningkatkan loyalitas muzaki adalah, pertama karena muzakki adalah orang yang berperan penting dalam mengeluarkan zakat baik zakat harta maupun zakat fitrah, kedua adalah adanya kenyataan bahwa tingkat kemampulabaan perusahaan berbanding lurus dengan pertumbuhan hubungan antara perusahaan dan muzaki secara permanen. Sikap loyal tersebut merupakan tujuan akhir dari perusahaan dalam membina muzaki.

Muzaki yang loyal merupakan aset penting bagi perusahaan dalam meningkatkan kualitas dan prospek prusahaan di masa datang. Berbeda dari kepuasan, yang merupakan sikap, loyalitas dapat didefinisikan berdasarkan perilaku membeli.

Iklan zakat melalui media online mempunyai pengaruh yang besar terhadap cara mempertahankan loyalitas muzakki Pada masa sulit inipun, masyarakat masih terikat dengan kemudahan-kemudahan yang disajikan oleh iklan yang disajikan pihak Baznas Provinsi Bali baik itu informasi tentang pembayaran zakat melalui aplikasi dan berbagai kemudahan 
lainnya. Tentu Muzakki akan lebih selektif dalam Informasi yang disajikan di media online, dan bahu membahu membantu para penerima zakat apalagi dimusim pandemi seperti ini.

Selain dari Iklan zakat melalui Media online, adapun faktor lain yang dapat mempengaruhi loyalitas muzaki di Baznas Provinsi Bali. Hal ini terlihat dari, hasil pengujian determinasi yang dihitung dengan melihat $\mathrm{R}$ Square sebesar 0,555 dikalikan $100 \%$ maka besarnya koefisien determinasi adalah :

$$
\begin{aligned}
\mathrm{D} & =\mathrm{R} \text { S quare X } 100 \% \\
& =0,555 \times 100 \% \\
& =55.5 \%
\end{aligned}
$$

Koefisien determinasi X1 dan X2 adalah sebesar $55.5 \%$ sedangkan sisanya $100 \%-55,5 \%=$ $45.5 \%$ dipengaruhi oleh faktor-faktor yang lain yang tidak diteliti dalam penelitian ini. Dari hasil pengujian diatas, dapat ditarik kesimpulan bahwa iklan zakat melalui media online memiliki pengaruh yang cukup besar yaitu $55.5 \%$. Penelitian ini sejalan dengan penelitian yang dilakukan oleh Ratna diantari yang berjudul "Analisis Pengaruh Iklan zakat menggunakan Media sosial, dan Kepuasan Muzaki (Studi Kasus Manajemen Bisnis Islam Kota Yogyakarta)". Penelitian ini membahas adakah pengaruh Iklan zakat menggunakan media sosial Terhadap Kepuasan Muzakki di Baznas Kota Yogyakarta dengan hasil kuesioner. Dari hasil penelitian tersebut dapat diperoleh kesimpulan bahwa, variabel Kualitas Produk, Kualitas Pelayanan Dan Harga berpengaruh signifikan terhadap kepuasan muzaki.$^{12}$

\section{PENUTUP}

Berdasarkan hasil analisis data melalui pembuktian terhadap hipotesis dari permasalahan yang diangkat, maka diambil simpulan dari penelitian sebagai berikut :

1. Untuk menjawab pembahasan pertama diperoleh hasil bahwa secara parsial terdapat pengaruh signifikan antara iklan zakat (X1) terhadap loyalitas muzaki (Y) sebesar 0,745 sedangkan square sebesar 0,555 yang berarti iklan (x1) media online (x2) terhadap loyalitas

12 Ratna diantari, Analisis Pengaruh Iklan zakat menggunakan Media Sosial, Terhadap Kepuasan Muzakki (Studi Kasus Manajemen Bisnis Islam Kota Yogyakarta)”, pada 20 maret 2019. muzaki (Y) di Baznas Provinsi Bali sebesar 55\% sisanya sebesar $45 \%$ dipengaruhi oleh faktorfaktor lain yang tidak diteliti dalam penelitian ini.

2. Untuk menjawab rumusan kedua diperoleh hasil bahwa terdapat pengaruh signifikasi antara variabel media online (X2) terhadap variabel loyalitas muzaki $(\mathrm{Y})$. terdapat pengaruh yang signifikan antara variabel media online (X2) terhadap variabel Loyalitas Muzakki (Y) Selain itu, media online (X2) memiliki t hitung lebih besar dari $\mathrm{t}$ tabel (t-hitung > $\mathrm{t}$-tabel) atau probabilitas kesalahan lebih kecil, hal ini sesuai dengan $\mathrm{Ha} 2$ yang menyatakan bahwa variabel media online berpengaruh positif

3. Berdasarkan rumusan masalah yang ketiga untuk mengetahui pengaruh secara simultan atau keseluruhan bisa dilihat dari uji $\mathrm{F}$ pada tabel 4.11 Anova, yaitu: variabel Iklan zakat (X1) dan media online (X2) berpengaruh secara signifikan terhadap loyalitas muzaki (Y) dengan hasil uji nilai Fhitung > F tabel 24,934> 3,23, dengan nilai signifikan $0,000<0,05$, sebesar 0,745 sedangkan square sebesar 0,555 yang berarti iklan zakat (X1) dan media online (X2) terhadap loyalitas muzaki (Y) di Baznas Provinsi Bali sebesar 55\% sisanya sebesar $45 \%$ dipengaruhi oleh variabel lain yang tidak diteliti dalam penelitian ini.

Berdasarkan dari hasil penelitian dan kesimpulan diatas, maka saya peneliti memberikan saran-saran diantaranya adalah:

1. Bagi pihak Baznas Provinsi Bali

a. Kepercayaan masyarakat terhadap Baznas Provinsi Bali sekiranya perlu ditingkatkan supaya masyarakat tetap berkomitmen membayarkan zakatnya melalui Baznas

a. Baznas Provinsi Bali perlu melakukan sosialisasi serta ajakan yang bersifat persuasif kepada masyarakat untuk membayar zakat di Baznas Provinsi Bali serta meningkatkan kreativitas ajakan berzakat di media sosial sehingga masyarakat mengetahui tentang pentingnya membayar zakat di Baznas Provinsi Bali

b. Bagi pihak Baznas Provinsi Bali diharapkan lebih meningkatkan lagi program-program, iklan dan sosialiasinya kepada masyarakat agar masyarakat lebih banyak mengenal baik diseluruh Kabupaten di Provinsi Bali dan menimbulkan ketertarikan masyarakat untuk membayar 
zakatnya di Baznas Provinsi Bali dan juga lebih transparan dalam penyaluran zakatnya

c. Baznas Provinsi dalam mengembangkan iklan atau promosi di beberapa media online seharusnya lebih terfokuskan lagi dan lebih baik mengadakan give away agar para pengikut di media sosial lebih antusias dan tidak merasa bosan

2. Bagi Penelitian Selanjutnya

a. Untuk memperoleh hasil studi yang lebih baik, maka perlu dilakukan uji lagi tentang faktor-faktor yang mempengaruhi ketaatan masyarakat membayar zakat di Baznas Provinsi Bali dengan menambahkan variabel bebas yang lebih banyak.

b. Untuk akademik penelitian ini diharapkan dapat dilanjutkan oleh peneliti lain dengan objek dan sudut pandang yang berbeda sehingga dapat memperkaya khasanah kajian ekonomi Islam.

DAFTAR RUJUKAAl- Musih Abdullah. 2004. Fiqih Ekonomi Syariah. Jakarta: Darul Faruk.

Alma, Buchari. 2004 Manajemen Pemasaran dan Pemasaran Jasa. Bandung: CV. Alfa Beta.

Badan Amil Zakat Nasional. 2013. Panduan Zakat Praktis, Jakarta: Badan Amil Zakat Nasional.

Basu, Swastha, 2007. Pengantar Bisnis Modern, Edisi ketiga, Cet ke-11, Yogyakarta: Liberty Yogyakarta.

Dyah Hasto \& Teguh Sri Pambudi. 2006. Advertising that sells. Jakarta: Gramedia Pustaka Utama.

Firdaus, Muhammad. 2011. Ekonometrika Suatu Pendekatan Aplikatif. Edisi Kedua, Jakarta: Bumi Aksara.

Ghazali, Imam. 2006. Aplikasi Analisis mulivarite dengan Program SPSS. Semarang: Badan Penerbit Universitas Diponegoro.

Ishak, Dahlan. 2000. Manajemen Zakat infaq dan shadaqah, Bandung: Insan Madani.

J. Supranto. 2004. M.A. Metode Ramalan Kuantitatif dan Perencanaan
Ekonomi dan Bisnis. Jakarta: PT.Rineka Cipta.

Kongrat, E. 2011. Model Strategi Promosi Stand Pameran pada Perusahaan. Jakarta: Jurnal Ekonomi.

Kurniasih. 2013. Penggunaan Media Sosial bagi Humas di Lembaga Pemerintah. Tangerang: Forum Kehumasan.

Kusmadi. 20011. Panduan Modern Penelitian Kuantitatif. Jakarta: Pustaka Pelajar.

Majid Khadduri. 1999. Teologi Keadilan Perspektif Islam. Surabaya: Risalah Gusti.

Morissan, 2012. Periklanan komunikasi pemasaran terpadu. Jakarta: kencana Prenada Media Group.

Mufraaini, Arief. 2012. Akuntansi Manajemen Zakat. Jakarta: Prenda Media Group.

Muhid, Abdul. AnalisiS Statistik (5 langkah Analisis Statistik dengan SPSS For Windows Sidoarjo: Zitama.

Nawawi, Ismail. 2010. Zakat dalam perpektif Fiqh, Sosial dan Ekonomi Surabaya: Putra Media Nusantara.

Nazir. 2005. Metode Penelitian Kuantitatif. Bogor: Ghalia Indonesia.

Philip, Kotler. 2005. Alih Bahasa Benyamin Molan. Manajemen Pemasaran, Edisi Kesebelas Jilid 1, Jakarta: PT Indeks.

Suryabrta, Sumadi. 2004. Metodologi Penelitian.Yogyakarta: Pustaka Pelajar.

Sugiyono. 2017. Statistika Untuk Penelitian. Bandung: Alfabeta.

Sutaryo. 2004. Dasar Dasar Sosialisasi, Jakarta: Rajawali Press.

S. Nasution. 2004. Sosiologi Pendidikan, Jakarta; Bumi Aksara. 
Yuliafitri, Indri. 2018. Pengaruh Kepercayaan, Transparansi, Akuntabilitas Terhadap Loyalitas Muzakki di LAZ Rumah Zakat.

Zuhaili, Wahbah. 2008. Al- Fiqh al Islami Wa Adillatuhu. Jakarta: Darul Fikir Gema Insani.

Kementrian Agama R.I. 2003. Panduan Organisasi Pengelolaan Zakat. Jakarta: Bimbingan Masyarakat Islam Direktorat Pemberdayaan Zakat.

Departemen Agama RI, 2005. Al- Jumatul Ali Al-Qur'an dan Terjemahnya, Bandung: CV Penerbit J-ART

Kementerian Agama RI. 2012. Al-Qur'an dan Terjemahannya. Jakarta: PT. Sinergi Pustaka Indonesia. 
